\title{
The Effect of Service and Location on Customer Satisfaction at the Andespar Manna Store, South Bengkulu
}

\section{Pengaruh Pelayanan Dan Lokasi Terhadap Kepuasan Pelanggan Di Toko Andespar Manna Bengkulu Selatan}

\author{
Eensi Nurye Friza 1); Sulisti Afriani ${ }^{2)}$; Nurzam²) \\ 1)Study Program of Accounting Faculty of Economic, Universitas Dehasen Bengkulu \\ 2) Department of managemen, Faculty of Economic, Universitas Dehasen Bengkulu \\ Email: enuryefriza@gmail.com
}

How to Cite :

Nurye Friza E. (2021). The Influence Of Location And Quality Of Service On Customer Satisfaction At Solo Eating House Jalan Lintas Manna Bengkulu EMAK: Jurnal Ekonomi Manajemen Akuntansi Dan Keuangan, 3(1). DOI: https://doi.org/10.53697/emak.v2i3

ARTICLE HISTORY

Received [1 Desember 2021]

Revised [10 Desember 2021]

Accepted [28 Desember 2021]

\section{KEYWORDS}

Service Effect, Location,

Customer Satisfaction

This is an open access article under the $C C-B Y$-SA license

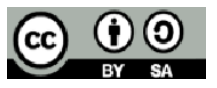

\section{ABSTRAK}

Tujuan dalam penelitian ini adalah untuk mengetahui pengaruh pelayanan dan lokasi terhadap kepuasan pelanggan di Toko Andespar Manna Bengkulu Selatan.Sampel dalam penelitian sebanyak 33 orang penjahit di Bengkulu Selatan yang berbelanja alat jahit dan dasar pada Toko Andespar Manna Bengkulu Selatan. Teknik pengambilan sampel adalah teknik accidental sampling. Pengumpulan data menggunakan kuesioner dan metode analisis yang digunakan adalah regresi linier berganda, uji determinasi dan uji hipotesis. Hasil regresi berganda menunjukan persamaan $Y=10,878+0,444 \mathrm{X} 1+0,364$ $\mathrm{X} 2+3,784$ arah regresi yang dihasilkan adalah positif sehingga mengandung arti bahwa semakin meningkat variabel pelayanan dan lokasi maka kepuasan pelanggan juga akan meningkat. Nilai koefesien determinasi sebesar 0,852. Hal ini berarti bahwa X1 (pelayanan) dan $\mathrm{X} 2$ (lokasi) memiliki kontribusi terhadap kepuasan pelanggan $(\mathrm{Y}$ ) sebesar 85,2 \% sedangkan sisanya $14,8 \%$ dipengaruhi oleh variabel-variabel lainnya yang tidak diteliti dalam penelitian ini. Secara keseluruhan, hasil uji $t$ memiliki nilai signfikan lebih kecil dari 0,05 , sehingga dapat diartikan bahwa X1 (pelayanan ) dan X2 (lokasi) memiliki pengaruh yang signfikan terhadap kepuasan pelanggan $(Y)$ secara parsial atau sendiri-sendiri. Hasil uji $F$ memiliki nilai signifikansi sebesar 0,000 0,05. Karena tingkat signifikansi di bawah 0,05 menunjukkan bahwa secara bersama-sama X1 (pelayanan) dan X2 (lokasi) mempunyai pengaruh yang signifikan terhadap kepuasan pelanggan $(\mathrm{Y})$.

\section{ABSTRACT}

The purpose of this study was to determine the effect of service and location on customer satisfaction at the Andespar Manna Bengkulu Selatan Shop. The sampling technique is accidental sampling technique. The data was collected using a questionnaire and the analytical methods used were multiple linear regression, determination test and hypothesis testing. Multiple regression results

94 | Eensi Nurye Friza, Sulisti Afriani, Nurzam; Effect of Motivation and Job Satisfaction... 


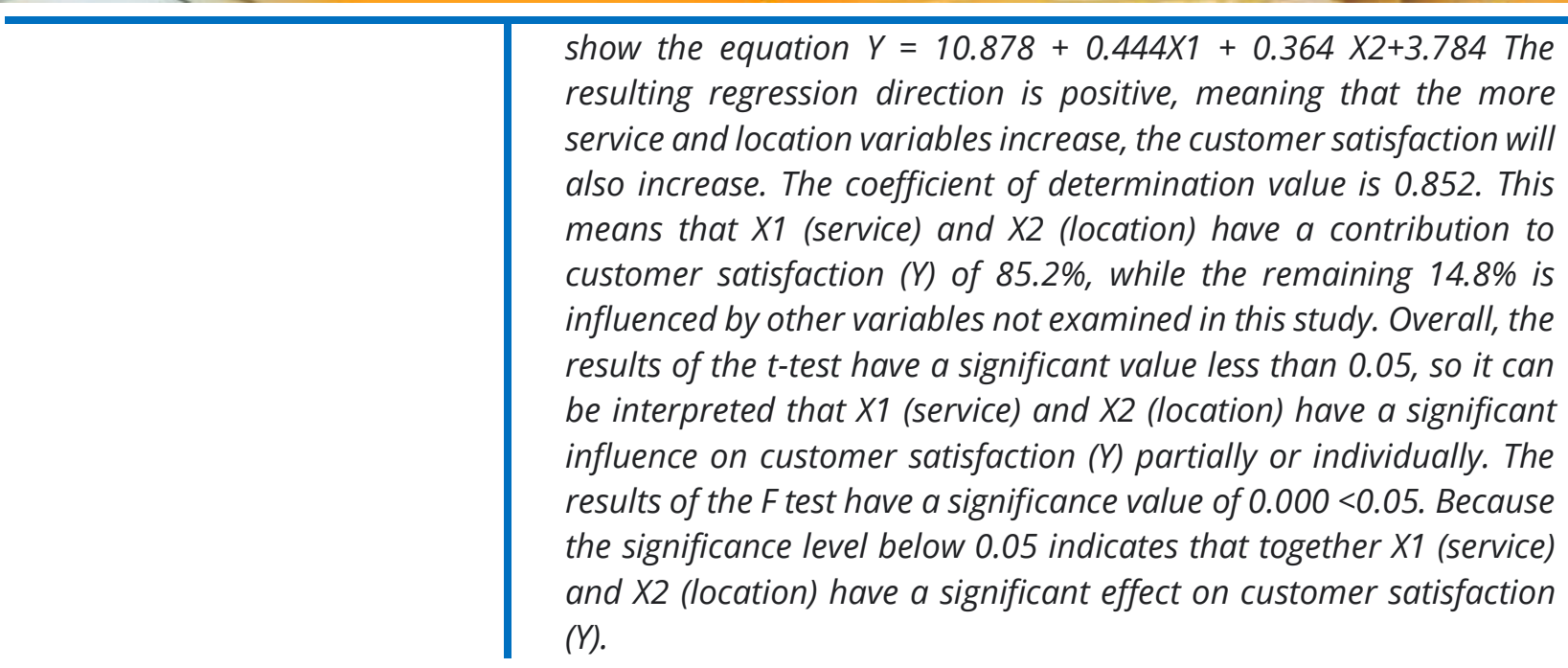

\section{PENDAHULUAN}

Perekonomian dunia saat ini memudahkan para pelaku usaha untuk menunjukkan kapasitas seriusnya dalam dunia usaha, dengan perekonomian dunia ini akan semakin mempertimbangkan kerjasama pertukaran antar lokal di seluruh Wilayah Bengkulu, ini merupakan kesempatan yang luar biasa bagi individu yang dapat memanfaatkannya, dengan pertukaran antar daerah Hal ini memungkinkan peningkatan pendapatan bagi organisasi, memenuhi kebutuhan di Sustenance City serta dengan pertukaran dunia juga siap untuk membangun kegunaan organisasi dengan memperluas permintaan di luar Bengkulu Selatan.

Iklan di Rezim Bengkulu Selatan jelas juga akan mempengaruhi kenaikan gaji, tetapi ini juga merupakan bahaya besar bagi perusahaan yang tidak dapat memanfaatkan situasi keuangan global ini, dengan perusahaan asing memasuki wilayah dengan kualitas yang lebih baik daripada kualitas perusahaan. Di Bengkulu Selatan, hal ini tentu akan menjadi cambukan bagi organisasi-organisasi di Kota Bengkulu.

Melihat besarnya peluang dan bahaya yang disajikan oleh organisasi, organisasi harus bekerja pada sifat baik dari sifat barang atau administrasi yang diberikan, untuk memiliki pilihan untuk memanfaatkan jeda keberuntungan yang ada dan mengurangi tingkat keuntungan. Bahayanya, karena tidak dapat dipungkiri bahwa selain kualitas barang, kualitas administrasi juga mempengaruhi organisasi agar tetap ekonomis. dicari, dengan alasan bahwa dengan bantuan yang luar biasa dapat menawarkan manfaat tambahan bagi organisasi.

Dengan bantuan yang besar akan mempererat hubungan antara organisasi dan tamu, sehingga akan membuat hubungan antara keduanya, sehingga pemilik toko akan tahu apa tahap selanjutnya untuk mengembangkan administrasi yang dirasa kurang ideal. dan tamu akan lebih terpenuhi.

Bantuan besar akan sangat mempengaruhi loyalitas konsumen. Dengan asumsi klien senang dengan administrasi yang diberikan, klien akan membuat tujuan pembelian pada klien. administrasi merupakan komponen yang signifikan, sedangkan faktor yang termasuk adalah bukti nyata (substansial), kualitas yang teguh (ketergantungan), (daya tanggap), penegasan (konfirmasi), dan simpati (kasih sayang). (Tjiptono, 2016:198)

Ide dasar administrasi adalah sekelompok penggambaran barang yang dapat mendorong loyalitas konsumen dan dapat meningkatkan nilai tambah suatu barang. Loyalitas konsumen adalah kondisi klien yang terpenuhi atau tidak puas setelah terpenuhinya keinginan dan asumsi atas menu, biaya, kantor dan administrasi yang diberikan. Klien akan merasa terpenuhi dengan asumsi keinginan dan asumsi yang didapat terpenuhi, pada kenyataannya pembeli akan merasa tidak puas jika keinginan dan asumsi yang didapat belum terpenuhi. Dengan cara ini, restoran yang perlu 
mendominasi dalam membuat loyalitas konsumen harus memiliki pilihan untuk fokus pada variabel yang mempengaruhinya.

Andespar adalah toko yang bergerak dibidang penjualan alat jahit dan dasar pakaian, terletak di Kota Medan Kecamatan Kota Manna Kabupten Bengkulu Selatan. Daribeberapa toko peralatan jahit yang berada di Manna, toko Andespar memiliki pelanggan yang cukup banyak. Berdasarkan hasil wawancara pra penelitian yang dilakukan dengan pemilik toko Andespar yaitu Bapak H. Riswan diketahui penjualan meningkat dari awal tahun sampai pertengahan tahun 2020, tetapi semenjak adanya pendami covid-19 yang telah melanda di kota Manna ini, terjadinya penurunan penjualan sampai Maret 2021 dan jumlah rata-rata pelanggan di bulan Januari sampai dengan Maret 2021 menjadi 30 orang penjahit di kota Manna.

Meskipun demikian toko Andespar tetap menjadi toko barang yang paling banyak diminati di Kabupaten Bengkulu Selatan dibandingkan dengan toko lain. Banyaknya peminat yang berbelanja dikarenakan lokasi Toko Andespar yang terletak di pusat Kota dan juga pelayanan yang sangat baik yang diberikan oleh pekerja di Toko Andespar terhadap pengunjung maupun pembeli yang datang.

\section{LANDASAN TEORI}

\section{Manajemen Pemasaran}

Menurut Gitosudarmo (2017: 3) mempromosikan para eksekutif adalah gerakan menampilkan yang sangat teratur, terkoordinasi, tersusun dan terarah yang akan menciptakan hasil yang dapat diterima.

Sunarto (2016:16) merekomendasikan bahwa papan iklan adalah pemeriksaan, pengaturan, pelaksanaan, dan pengendalian proyek yang dimaksudkan untuk membuat, membangun, dan mengikuti perdagangan produktif dengan pembeli sasaran untuk mencapai tujuan organisasi.

\section{Administrasi}

Menurut Wijaya (2014:52), kualitas administrasi adalah proporsi seberapa baik derajat administrasi yang diberikan dapat memenuhi asumsi klien. Sesuai Tjiptono (2016:59) menyatakan bahwa bantuan adalah derajat kebesaran yang diharapkan dan perintah atas derajat kebesaran untuk memenuhi keinginan klien.

Sebagaimana ditunjukkan oleh Ibrahim dalam Hardiyansyah (2015: 40) Administrasi adalah suatu kondisi unik yang diidentifikasikan dengan item, administrasi, individu, proses, dan iklim di mana penilaian tidak ditetapkan pada saat pengaturan administrasi publik tersebut.

Stemvelt (2016: 210) menyatakan bahwa gagasan kualitas administrasi adalah kesan dari gangguan kualitas umum yang digagas dan berubah menjadi pemikiran yang harus direncanakan (merinci) sehingga penerapannya (eksekusi) dapat diuji ulang (penilaian), untuk berubah menjadi interaksi yang unik, maju, konsisten dalam mengumpulkan loyalitas konsumen. Dengan asumsi bantuan yang didapat atau dilihat benar adanya, maka pada saat itu kualitas bantuan dipandang baik dan enak.

\section{Daerah}

Memilih area bisnis adalah pilihan bisnis yang harus dilakukan dengan hati-hati. Menurut Heizer dan Render (2015: 554) area merupakan penggerak pengeluaran dan pendapatan, sehingga area seringkali memiliki kemampuan untuk membuat teknik bisnis suatu organisasi. Area esensial berarti memperluas keunggulan area baru organisasi.

Area adalah saluran angkut, tepatnya cara yang digunakan untuk memindahkan barang dari pembuat ke pelanggan. Area adalah pilihan yang dibuat oleh organisasi dalam kaitannya dengan di mana kegiatan dan stafnya akan ditemukan (Lupiyoadi, 2015: 96). Sementara itu, seperti yang ditunjukkan oleh Swastha dan Handoko, (2016: 187) mengusulkan bahwa area (tempat) menunjukkan berbagai latihan yang dilakukan oleh organisasi untuk membuat barangnya mungkin dan dapat diakses oleh pembeli. 


\section{Loyalitas konsumen}

Menurut Tjiptono (2016: 353) pemenuhan berasal dari bahasa latin "satis" yang berarti cukup atau memuaskan dan "facio" berarti melakukan atau membuat. Pemenuhan pembeli adalah evaluasi setiap pelanggan dengan membandingkan kondisi saat ini dan kondisi normal. Jika barang atau administrasi yang diberikan oleh perusahaan sesuai dengan asumsi klien, klien akan merasa terpenuhi. Kemudian lagi, jika barang atau administrasi yang diberikan oleh organisasi tidak memenuhi asumsi klien, klien akan merasa frustrasi.

Kotler dan Keller (2014: 177), menyatakan pemenuhan itu adalah sensasi kegembiraan atau kekecewaan individu yang muncul setelahnya mengontraskan pameran (atau hasil) yang tampak dari item tersebut dengan presentasi (atau hasil) normal. Pada akhirnya, seseorang merasa puas jika hasil yang diperoleh pada dasarnya siap untuk memenuhi keinginannya, sementara seseorang merasa kecewa jika hasil yang didapat tidak sesuai dengan keinginannya.

\section{METODE PENELITIAN}

\section{Regresi Linear Berganda}

Analisis regresi linier berganda adalah teknik statistika yang berguna untuk memerikasa dan memodelkan hubungan diantara variabel-variabel. Regresi berganda sering kali digunakan untuk mengatasi permasalahan analisis regresi yang mengakibatkan hubungan dari dua atau lebih variabel bebas. Model persamaan regresi linier berganda sebagai berikut (Sugiyono, 2016:192) :

$$
\begin{array}{ll} 
& Y=a+b_{1} \mathbf{X}_{1}+\mathbf{b}_{2} \mathbf{X}_{2}+\mathbf{e} \\
\text { Keterangan : } & \\
Y & =\text { Kepuasan Pelanggan } \\
X_{1} & =\text { Pelayanan } \\
X_{2} & =\text { Lokasi } \\
\mathrm{a} & =\text { Nilai konstanta } \\
\mathrm{e} & =\text { error }
\end{array}
$$

Analisa regresi berganda ini dimaksudkan untuk mengetahui tingkat pengaruh dari masing-masing variabel bebas terhadap variabel tergantung secara kuantitatif. Besarnya pengaruh dari masingmasing variabel bebas tersebut dapat diperkirakan dengan melakukan interpretasi angka koefisien regresi partial b.

\section{Analisis Korelasi Berganda}

Menurut Sugiyono (2016:231) korelasi berganda merupakan angka yang menunjukkan arah dan kuatnya hubungan antara dua variabel indenpenden secara bersama-sama atau lebih dengan satu variabel dependen. Untuk dapat memberikan penafsiran terhadap koefesien korelasi yang ditemukan tersebut besar atau kecil, maka dapat berpedoman pada ketentuan sebagai berikut Tabel 1. Interprestasi Koefisien Korelasi

\begin{tabular}{|c|c|}
\hline Interval Koefesien & Tingkat Hubungan \\
\hline $0,00-0,199$ & Sangat rendah \\
\hline $0,20-0,399$ & Rendah \\
\hline $0,40-0,599$ & Sedang \\
\hline $0,60-0,799$ & Kuat \\
\hline $0,80-1,000$ & Sangat kuat \\
\hline
\end{tabular}

Sumber : Sugiyono, 2016:184

\section{Koefisien Determinasi}

Koefisien determinasi $\left(R^{2}\right)$ pada intinya mengukur seberapa jauh kemampuan model dalam menerangkan variasi variabel dependen. Nilai koefisien determinasi adalah antara nol sampai satu (0 $<\mathrm{R}^{2}<1$ ). Nilai $\mathrm{R}^{2}$ yang kecil berarti kemampuan variabel-variabel independen dalam menjelaskan variasi variabel dependen sangat terbatas. Nilai yang mendekati satu berarti variabel-variabel 
independen memberikan hampir semua informasi yang dibutuhkan untuk memprediksi variasi variabel dependen.

\section{HASIL PENELITIAN DAN PEMBAHASAN}

\section{Analisis Regresi Berganda}

Analisis regresi berganda digunakan untuk mengetahui besarnya pengaruh pelayanan dan lokasiterhadap kepuasan pelanggan pada Toko Andespar Manna Bengkulu Selatan. Perhitungan statistik dalam analisis regresi berganda dijelaskan pada tabel 2. berikut ini :

Tabel 2. Hasil Uji Regresi Berganda

\section{Coefficients $^{a}$}

\begin{tabular}{|c|c|c|c|c|c|c|}
\hline \multirow{2}{*}{\multicolumn{2}{|c|}{ Model }} & \multicolumn{2}{|c|}{ Unstandardized Coefficients } & Standardized Coefficients & \multirow[b]{2}{*}{ t } & \multirow[b]{2}{*}{ Sig. } \\
\hline & & B & Std. Error & Beta & & \\
\hline \multirow[t]{3}{*}{1} & (Constant) & 10.878 & 3.784 & & 2.875 & .007 \\
\hline & Pelayanan & .444 & .123 & .547 & 3.622 & .001 \\
\hline & Lokasi & .364 & .137 & .403 & 2.666 & .012 \\
\hline
\end{tabular}

a. Dependent Variable: Kepuasan

Sumber: Hasil Penelitian dan diolah, 2021

Dari hasil perhitungan regresi linear berganda dengan menggunakan program SPSS 21.00 maka dapat diperoleh perseamaan regresi linier berganda sebagai berikut:

Keterangan:

$$
Y=10,878+0,444 X_{1}+0,364 X_{2}+3,784
$$

$Y \quad=$ Kepuasan pelanggan

$\mathrm{X}_{1}=$ Pelayanan

$\mathrm{X}_{2}=$ Lokasi

Persamaan regresi tersebut dapat dijelaskan sebagai berikut :

1. Nilai konstanta 10,878 mempunyai arti bahwa apabila variabel Pelayanan $\left(X_{1}\right)$ dan Lokasi $\left(X_{2}\right)$ dianggap tetap maka variabel Kepuasan pelanggan $(Y)$ akan tetap sebesar 10,878

2. Pengaruh Pelayanan $\left(X_{1}\right)$ terhadap Kepuasan pelanggan $(Y)$

Nilai koefesien regresi variabel $X_{1}$ (Pelayanan) adalah sebesar 0,444 dengan asumsi apabila $X_{1}$ (Pelayanan) mengalami kenaikan sebesar satu-satuan maka $Y$ (Kepuasan pelanggan) juga akan mengalami kenaikan sebesar 0,444 kali.

3. Pengaruh Lokasi $\left(\mathrm{X}_{2}\right)$ terhadap Kepuasan pelanggan $(\mathrm{Y})$

Nilai koefesien regresi variabel $\mathrm{X}_{2}$ (Lokasi) adalah sebesar 0,364 dengan asumsi apabila $\mathrm{X}_{2}$ (Lokasi) mengalami kenaikan sebesar satu-satuan maka $Y$ (Kepuasan pelanggan) juga akan mengalami kenaikan sebesar 0,364 kali.

\section{Korelasi Berganda (R)}

Uji korelasi berganda digunakan untuk mengetahui hubungan pelayanan dan lokasiterhadap kepuasan pelanggan pada Toko Andespar Manna Bengkulu Selatan. Hasil perhitungan korelasi berganda adalah sebagai berikut

Tabel 3. Koefesien Korelasi Berganda (R)

\begin{tabular}{|l|r|r|r|r|}
\hline \multicolumn{1}{|c|}{ Model Summary } \\
\hline 1 & \multicolumn{1}{|c|}{ R } & \multicolumn{1}{|c|}{ R Square } & Adjusted R Square & Std. Error of the Estimate \\
\hline
\end{tabular}

a. Predictors: (Constant), Lokasi, Pelayanan

Sumber: Output SPSS Versi 21.0, 2021

98 | Eensi Nurye Friza, Sulisti Afriani, Nurzam; Effect of Motivation and Job Satisfaction... 
Keterangan :

$\begin{array}{ll}0,00-0,199 & \text { Sangat Rendah } \\ 0,20-0,399 & \text { Rendah } \\ 0,40-0,599 & \text { Sedang } \\ 0,60-0,674 & \text { Kuat } \\ 0,80-1,000 & \text { Sangat Kuat }\end{array}$

Sumber : Sugiyono (2013:184)

Berdasarkan output tersebut dapat dilihat bahwa koefisien korelasi antara variabel independent dan dependent sebesar 0,923. Koefisien korelasi bertanda positif artinya korelasi yang terjadi antara variabel X1 (pelayanan), dan X2 (lokasi), terhadap kepuasan pelanggan (Y)adalah searah, dimana semakin besar variabel independent maka akan diikuti oleh semakin besarnya variabel dependent. Nilai 0,923 menunjukan korelasi dalam kategori hubungan yang sangat kuat karena angka 0,923terletak pada interval 0,80 - 1,000.

\section{Koefisien Determinasi (R2)}

Koefisien determinasi ini digunakan untuk mengetahui seberapa besar pengaruh variabelvariabel bebas memiliki pengaruh terhadap variabel terikatnya. Nilai koefisien determinasi ditentukan dengan nilai adjusted R square tabel 3.

Untuk nilai koefesien determinasi menggunakan model $\mathrm{R}$ square. Dari hasil perhitungan dengan menggunakan SPSS dapat diketahui nilai koefesien determinasi dari R square yaitu sebesar 0,852. Hal ini berarti bahwa X1 (pelayanan ) dan X2 (lokasi) memiliki kontribusi terhadap kepuasan pelanggan $(Y)$ sebesar $85,2 \%$ sedangkan sisanya $14,8 \%$ dipengaruhi oleh variabel-variabel lainnya yang tidak diteliti dalam penelitian ini..

Uji t

Uji t digunakan untuk melihat pengaruh dari masing-masing variabel $X$ secara sendiri-sendiri atau terpisah terhadap variael Y. Hasil pengujian hipotesis uji t dengan menggunakan SPSS 21.00 adalah sebagai berikut :

Tabel 4. Hasil Uji t

Coefficients $^{\mathrm{a}}$

\begin{tabular}{|c|c|c|c|c|c|c|}
\hline \multirow{2}{*}{\multicolumn{2}{|c|}{ Model }} & \multicolumn{2}{|c|}{ Unstandardized Coefficients } & \multirow{2}{*}{\begin{tabular}{|c} 
Standardized Coefficient \\
Beta \\
\end{tabular}} & \multirow[b]{2}{*}{ t } & \multirow[b]{2}{*}{ Sig. } \\
\hline & & B & Std. Error & & & \\
\hline \multirow[t]{3}{*}{1} & (Constant) & 10.878 & 3.784 & & 2.875 & .007 \\
\hline & Pelayanan & .444 & .123 & .5 & 3.622 & .001 \\
\hline & Lokasi & .364 & .137 & .4 & 2.666 & .012 \\
\hline
\end{tabular}

a. Dependent Variable: Kepuasan

Sumber: Hasil Penelitian dan diolah, 2021

"Dari hasil perhitungan di atas maka dapat dijelaskan sebagai berikut:

1. Variabel X1 (Pelayanan)

Hasil pengujian untuk variabel X1 (pelayanan )menunjukkan nilai signifikansi sebesar 0,001 $<0,05$. Karena nilai signifikansi lebih kecil dari 0,05, maka H0 ditolak dan Ha diterima. Artinya X1 (pelayanan )memiliki pengaruh yang positif dan signifikan terhadap Kepuasan pelanggan (Y).

2. Variabel X2 (Lokasi)

Hasil pengujian untuk variabel X2 (Lokasi)menunjukkan nilai signifikansi sebesar 0,012< 0,05. Karena nilai signifikansi lebih kecil dari 0,05, maka H0 ditolak dan Ha diterima. Artinya X2 (Lokasi)memiliki pengaruh yang positif dan signifikan terhadap Kepuasan pelanggan ( $\mathrm{Y}$ ) 
Uji F

Uji F digunakan untuk melihat pengaruh seluruh variabel yaitu X1 (pelayanan) dan X2 (lokasi) berpengaruh secara bersama-sama terhadap kepuasan pelanggan $(\mathrm{Y})$. Berdasarkan hasil pengujian hipotesis Uji Anova atau uji F terlihat pada tabel berikut.

Tabel 5. Hasil Uji F

\begin{tabular}{|c|c|c|c|c|c|}
\hline \multicolumn{6}{|c|}{ AINUVA } \\
\hline Model & Sum of Squares & df & Mean Square & $\mathrm{F}$ & Sig. \\
\hline Regression & 975.767 & 2 & 487.883 & 86.534 & $.000^{b}$ \\
\hline Residual & 169.142 & 30 & 5.638 & & \\
\hline Total & 1144.909 & 32 & & & \\
\hline
\end{tabular}

a. Dependent Variable: Kepuasan

b. Predictors: (Constant), Lokasi, Pelayanan

Sumber: Hasil Penelitian (Lampiran 9) dan diolah, 2021

Berdasarkan Tabel 5. di atas diketahui nilai signifikansi sebesar 0,000 $<0,05$. Karena tingkat signifikansi kurang dari 0,05 menunjukkan bahwa secara bersama-sama X1 (pelayanan ) dan X2 (lokasi) mempunyai pengaruh yang positif dan signifikan terhadap kepuasan pelanggan $(Y)$

Berdasarkan hasil uji simultan maka HO ditolak dan Ha diterima, antara Variabel-variabel bebas yaituX1 (pelayanan) dan X2 (lokasi) mempunyai pengaruh yang signifikan secara bersama-sama terhadap Kepuasan pelanggan $(\mathrm{Y})$..

\section{Pengaruh Pelayanan Terhadap Kepuasan Pelanggan Toko Andespar}

Hasil pengujian pada penelitian ini menunjukkan bahwa terdapat pengaruh yang signifikan antara pelayanan terhadap kepuasan pelanggan pada Toko Andespar Manna Bengkulu Selatan, karena nilai signifikan sebesar 0,001 lebih kecil dari 0,05. Hal ini menggambarkan bahwa semakin meningkat pelayananyang diberikan oleh Toko Andespar Manna Bengkulu Selatan maka kepuasan pelanggan juga akan semakin meningkat meningkat..

Hasil penelitian di Toko Andespar Manna Bengkulu Selatan menyatakan bahwa pelayanan memiliki pengaruh positif dan signifikan terhadap kepuasan pelanggan dikarenakan ada beberapa faktor, misalnya karyawan membantu pelanggan yang terlihat sedang bingung memilih dasar pakaian maupun peralatan jait yang akan dibeli, pelayanan yang baik di Toko Andespar Manna Bengkulu Selatan sudah dapat membentuk kepuasan konsumen. Kepuasan pelanggan tercipta karena adanya hubungan yang harmonis antar pelanggan dengan Toko Andespar Manna Bengkulu Selatan.

Pelayanan yang diberikan oleh karyawan Toko Andespar Manna dapat dilihat dari cara karyawan memberikan perhatian kepada pelanggan dengan cara menjelaskan macam-macam pelatan jahit yang tersdia, karayawan akan memerikan pilihan kepada pelanggan seperti dalam pembelian dasar pakaian. Karyawan akan menjelaskan kelebihan dan kekurangan dari dasar yang akan dibeli dan juga menjelaskan harga dari dasar yang akan dijual. Untuk peralatan jait juga berbagai macam merek dan jenisnya, karyawan juga akan menjelaskan tentang peralatan jait yang disediakan. Selain itu di Toko Andespar juga tersedia tempat atau ruang tunggu pada saat berbelanja.

Hubungan harmonis itu tercipta karena adanya kepuasan dari pihak pelanggan. Penelitian ini menunjukkan ada pengaruh antara pelayanan terhadap kepuasan konsumen. Artinya, pelayanan karyawan rumah makan yang baik mempengaruhi kepuasan konsumen atau membentuk suatu sikap loyal konsumen. Hal ini disebabkan karena pelayanan yang diberikan oleh karyawan Toko Andespar Manna Bengkulu Selatan sudah cukup optimal, misalnya dalam merespon dan bertindak cepat untuk melayani konsumen.

Menurut Tjiptono (2015:59), kualitas layanan adalah tingkat keunggulan yang diharapkan dan pengendalian atas tingkat keunggulan tersebut untuk memenuhi keinginan pelanggan. Hal ini 
menggambarkan dengan adanya pelayanan maksimal yang diberikan oleh Toko Andespar Manna Bengkulu Selatan kepada para pelanggan, dan pelanggan merasa terpuaskan dengan pelayanan tersebut maka pelanggan akan selalu berbelanja kebutuhan alat jaitnya pada Toko Andespar Manna Bengkulu Selatan.

Hasil penelitian ini sejalan dengan penelitian terdahulu yang dilakukan oleh Hanita (2015) yang menemukan adanya hubungan yang signfikan antara kualitas pelayanan dengan kepuasan.

\section{Pengaruh Lokasi Terhadap Kepuasan Pelanggan Toko Andespar}

Hasil pengujian pada penelitian ini menunjukkan bahwa terdapat pengaruh yang signifikan antara lokasi terhadap kepuasan pelanggan pada Toko Andespar Manna Bengkulu Selatan karena nilai signifikan sebesar 0,012 lebih kecil dari 0,05. Hal ini menggambarkan bahwa semakin strategis lokasi maka kepuasan pelanggan pada Toko Andespar Manna Bengkulu Selatan juga akan semakin meningkat.

Lokasi Toko Andespar Manna yang terletak di pinggir jalan raya akan memudahkan bagi konsumen untuk berbelanja peralatan jait di toko Andespar Manna Bengkulu Selatan. Selain itu toko Andespar juga menyediakan lahan parkir dan bebas parkir sehingga pelanggan merasa nyaman untuk memarkir kendaraannya meskipun berbelanja cukup lama. Lokasi parkir Toko Andespar sangat memadai baik untuk kendaraan roda dua maupun kendaraan roda empat.

Saat lokasi yang berorientasi terhadap konsumen maka lokasi tersebut haruslah memenuhi keinginan konsumen dan memberikan kemudahan bagi konsumen seperti kemudahan dalam waktu dan tempat. Lokasi perusahaan perlu berada dekat dengan pusat kota atau perumahan, kondisi lahan parkir dan transportasi menuju perusahaan. Karena lokasi yang strategis dan mudah dicapai kendaraan umum akan menjadi daya tarik bagi pelanggan (Alma, 2017:101).

Hasil penelitian ini sejalan dengan penelitian terdahulu yang dilakukan oleh Hidayat (2019) yang menemukan adanya pengaruh yang signfikan antara lokasi dengan kepuasan pelanggan.

\section{Pengaruh Pelayanan dan Lokasi Terhadap Kepuasan Pelanggan Toko Andespar}

Hasil penelitian menunjukkan adanya pengaruh yang signifikan secara bersama-sama antara pelayanan dan lokasi terhadap kepuasan pelanggan pada Toko Andespar Manna Bengkulu Selatan karena nilai signifikan sebesar 0,000 kecil dari 0,05 sehingga dapat diartikan bahwa pelyanan dan lokasi berpengaruh secara bersama-sama terhadap kepuasang pelanggan.

Pelayanan yang maksimal akan memberikan kepuasan terhadap pelanggan sehingga pelanggan akan merasa puas terhadap pelayanan yang diberikan dan juga pelanggan akan memberitahukan kepada kerabatnya kalau pelayanan yang diberikan oleh Toko Andespar membuat mereka puas. Selain itu lokasi toko Andespar yang strategis dan mudah dijangkau dapat juga membuat konsumen merasa puas dan akan tetap berbelanja di toko Andespar Manna Bengkulu Selatan.

\section{KESIMPULAN DAN SARAN}

\section{Kesimpulan}

1. Hasil pengujian untuk variabel X1 (pelayanan )menunjukkan nilai signifikansi sebesar $0,001<0,05$. Karena nilai signifikansi lebih kecil dari 0,05, maka HO ditolak dan Ha diterima. Artinya X1 (pelayanan )memiliki pengaruh yang positif dan signifikan terhadap Kepuasan pelanggan ( $\mathrm{Y}$ ).

2. Hasil pengujian untuk variabel $X 2$ (Lokasi)menunjukkan nilai signifikansi sebesar $0,012<0,05$. Karena nilai signifikansi lebih kecil dari 0,05, maka HO ditolak dan Ha diterima. Artinya X2 (Lokasi)memiliki pengaruh yang positif dan signifikan terhadap Kepuasan pelanggan ( $\mathrm{Y}$ ).

3. Hasil uji $\mathrm{F}$ memiliki nilai signifikansi sebesar $0,000<0,05$. Karena tingkat signifikansi di bawah 0,05 menunjukkan bahwa secara bersama-sama X1 (pelayanan) dan X2 (lokasi) mempunyai pengaruh yang signifikan terhadap kepuasan pelanggan $(\mathrm{Y})$. 


\section{Saran}

1. Untuk Lokasi diharapkan kepada Toko Andespar Manna Bengkulu Selatan untuk lebih memperluas area parkir karena lokasi toko yang terletak di pinggir jalan dapat mengganggu kelancaran lalu lintas.

2. Diharapkan kepadaToko Andespar Manna Bengkulu Selatanuntuk dapat memaksimalkan pelayanan antar alamat, karena pada saat pandemi Covid 19 ini masyarakat lebih di anjrukan untuk tetap dirumah

\section{DAFTAR PUSTAKA}

Ghozali, Imam. 2015. Aplikasi Analisis Multivariate dengan Program IBM SPSS 23. Semarang : Badan Penerbit Universitas Diponegoro.

Hanita. 2015. Hubungan Kualitas Pelayanan dan Promosi terhadap Keputusan Nasabah dalam Menabung pada PT. Bank Bengkulu Cabang Manna. Skripsi Universitas Dehasen Bengkulu

Hardiyansyah. 2015. Kualitas Pelayanan Publik Konsep, Dimensi, Indikator dan Implementasinya.Yogyakarta : Gava Media.

Heizer, Jay and Render Barry, 2015, Manajemen Operasi, Manajemen Keberlangsungan dan Rantai Pasokan, edisi 11. Jakarta: Salemba Empat

Hidayat 2019. Pengaruh Suasana Toko dan Lokasi Terhadap Minat Beli Ulang Konsumen di. UD. Naysila Toys Simpang SKPD. Jurnal Ekonomi Vol. 2. No. 3

Kasmir. 2017. Customer Service Excellent. PT Raja Grafindo Persada. Depok.

Kotler dan Keller. 2014. Manajemen Pemasaran. Jilid I. Edisi Ke 13. Jakarta: Erlangga

Lupiyoadi, Rambat. 2015. Manajemen Pemasaran Jasa Berbasis Kompetensi (Edisi 3). Jakarta: Salemba Empat

Nugroho dan Ratih Paramita. 2015. Analisis Pengaruh Lokasi, Keanekaragaman Barang Terhadap Keputusan Berbelanja dan Loyalitas Konsumen di Carrefour Semarang. EKOBIS vol. 2 no. 1. Universitas Islam Sultan Agung, Semarang.

Ratnasari Tri Ririn, Mastuti H Aksa. 2013. Manajemen Pemasaran Jasa. Penerbit: Ghalia Indonesia Stemvelt, R.C. 2016. (Diterjemahkan oleh Purwoko) Perception of Service Quality. Allyn and Bacon, Massachusetts.

Sunyoto, Danang. 2013. Dasar-Dasar Manajemen Pemasaran. Yogyakarta: CAPS

Swastha, Basu dan Handoko Hani, 2016. Manajemen Perusahaan Analisa Perilaku Konsumen, Yogyakarta : Liberty Edisi Pertama

Tjiptono, Fandy. 2016, Pemasaran Jasa - Prinsip, Penerapan, dan Penelitian, Andi Offset, Yogyakarta. Wijaya, T. 2014. Manajemen Kualita Jasa. Jakarta: Indeks.

Wulandari. 2013. Pengaruh Kualitas Peroduk, Kualitas Pelayanan Dan Lokasi

Yong, C.Z., Yun, Y.W., Loh, L., 2016. . (Diterjemahkan oleh Sutanto). The Quest for Global Quality. Pustaka Delapratasa, Jakarta

102 | Eensi Nurye Friza, Sulisti Afriani, Nurzam; Effect of Motivation and Job Satisfaction... 